\title{
Effects of Drought Stress Simulated by Polyethylene Glycol on Seed Germination, Root and Seedling Growth, and Seedling Antioxidant Characteristics in Job's Tears
}

\author{
Can Wang, Lingbo Zhou, Guobing Zhang, Yan Xu, Xu Gao, Ne Jiang, Liyi Zhang, Mingbo Shao \\ Institute of Upland Food Crops, Guizhou Academy of Agricultural Sciences, Guiyang, China \\ Email: 563189433@qq.com
}

How to cite this paper: Wang, C., Zhou, L.B., Zhang, G.B., Xu, Y., Gao, X., Jiang, N., Zhang, L.Y. and Shao, M.B. (2018) Effects of Drought Stress Simulated by Polyethylene Glycol on Seed Germination, Root and Seedling Growth, and Seedling Antioxidant Characteristics in Job's Tears. Agricultural Sciences, 9, 991-1006.

https://doi.org/10.4236/as.2018.98069

Received: August 3, 2018

Accepted: August 18, 2018

Published: August 21, 2018

Copyright $\odot 2018$ by authors and Scientific Research Publishing Inc. This work is licensed under the Creative Commons Attribution International License (CC BY 4.0).

http://creativecommons.org/licenses/by/4.0/

\begin{abstract}
Two Job's tears cultivars, yy18-1 (high resistance to drought stress) and yy12-7 (susceptible to drought stress) were used to investigate the responses of seed germination, root and seedling growth, and seedling antioxidant characteristics to drought stress simulated by polyethylene glycol (PEG) 6000 solutions with $0,-0.05,-0.1,-0.15$, and $-0.2 \mathrm{MPa}$ osmotic potentials. The results showed that the germination energy, germination rate, germination index, root and seedling lengths, root and seedling diameters, root and seedling fresh masses, root and seedling dry masses, and seedling relative water content (RWC) decreased with the decrease of the osmotic potential of PEG 6000 solution. The contents of hydrogen peroxide $\left(\mathrm{H}_{2} \mathrm{O}_{2}\right)$, malondialdehyde (MDA), and proline in seedling increased with the decrease of the osmotic potential of PEG 6000 solution. The activities of peroxidase (POD), catalase (CAT), ascorbate peroxidase (APX), and glutathione reductase (GR) in seedling increased and then decreased with the decrease of osmotic potential of PEG 6000 solution. $-0.1 \mathrm{MPa}$ was the optimal osmotic potential of PEG 6000 solution simulated drought stress at germination stage for Job's tears. The proline content and activities of POD and CAT were important mechanisms for the maintenance of drought resistance in Job's tears seedling.
\end{abstract}

\section{Keywords}

Antioxidant Characteristics, Drought Stress, Germination, Growth, Job's Tears, Polyethylene Glycol

\section{Introduction}

Job's tears (Coxi lacryma-jobi L.) belongs to the Coix of Gramineae, which has a 
long cultivation history as a traditional Chinese herbal medicine. It is widely cultivated in some Asian countries including China, Japan, Korea, Philippines, Thailand, Vietnam, and Burma. China is the largest producer of Job's tears, especially Guizhou province in southwest China [1]. Job's tears has been praised as the king of Gramineae crops due to its high nutritional value. It is rich in protein, essential amino acid, vitamins, minerals, dietary fibre, fatty acid, carbohydrates, oligosaccharides, coixenolide, and coixol, which is used as porridge, flour, noodle, or drink [2]. Besides, Job's tears can be used to defend against cancer, cure warts, suppress colon carcinogenesis, regulate blood sugar level, cure chronic diarrhea, cure dermatophytosis, prevent gallstone formation, cure edema, and clear heat [3].

Drought is one of the most devastating environmental stresses, which is a major environmental factor contributing to the reduction in growth, development and production of crops. It has been estimated that over $26 \%$ of cultivated lands worldwide are affected by drought [4]. Germination is one of the most important stages in the crop life cycle and resistance against drought during the germination makes a crop stable [5]. Drought stress is responsible for both inhibition or delayed seed germination and seedling establishment. The first symptom of drought stress is rapid inhibition of shoot and, to a lesser extent, root growth [6]. The production of reactive oxygen species (ROS) such as hydrogen peroxide $\left(\mathrm{H}_{2} \mathrm{O}_{2}\right)$, super oxide $\left(\mathrm{O}_{2}^{-}\right)$, and hydroxyl radical $\left(\mathrm{OH}^{-}\right)$can disrupt normal metabolism in drought stress through oxidative damage to lipids, proteins and nucleic acids [7]. The antioxidant defense system is present in the plant cells for ROS detoxification constitutes both antioxidant enzymes and non-enzyme antioxidant metabolites. Antioxidant enzymes contain superoxide dismutase (SOD), peroxidase (POD), catalase (CAT), ascorbate peroxidase (APX), and glutathione reductase (GR). Non-enzyme antioxidant metabolites include ascorbic acid, reduced glutathione, carotenoids, and flavonoids [8]. In drought resistance, high contents of non-enzyme antioxidant metabolites and activities of antioxidant enzymes are important.

Polyethylene glycol (PEG) is a group of neutral osmotically active polymers with a certain molecular weight, which is inert, no-ionic, virtually impermeable to cell membranes, and can induce uniform water stress without causing direct physiological damage [9]. It has been widely used to study crops response to drought stress during germination stage [10]. The adverse effects of drought stress on seed germination, root growth, and seedling growth have been well reported in various crops such as sorghum, pinto bean, and wheat [11]. However, little is known about the effect of drought stress on germination in Job's tears, especially regarding drought stress simulated by PEG. In the present work, five different concentrations of PEG were used to imitate different levels of drought stress in two different cultivars of Job's tears. Changes in seed germination parameters, root and seedling growth parameters, and seedling antioxidant characteristics of seedling were examined and compared in two Job's tears cultivars. 
A greater understanding of that information can provide a theoretical basis for the researches on drought resistance identification, drought resistance indices screening, drought resistance cultivar breeding, drought resistance mechanism, and drought regulation and alleviation mechanism in Job's tears.

\section{Materials and Methods}

\subsection{Plant Materials and Chemicals}

The PEG 6000 was purchased from Shanghai Sangon Biotechnology Co., Ltd, Shanghai, China. The plant materials were two Job's tears cultivars with different drought resistance; yy18-1 is high resistance to drought stress with black seed coat and yy12-7 is susceptible to drought stress with white seed coat, which were approved by the Guizhou Crop Cultivar Approval Committee (Guiyang, Guizhou Province, China) in 2016. Seeds of Job's tears cultivars were kindly provided by Institute of Upland Food Crops, Guizhou Academy of Agricultural Sciences, Guiyang, China.

\subsection{Experimental Design}

The experiments were conducted as completely randomized design with three replications at the Institute of Upland Food Crops, Guizhou Academy of Agricultural Sciences, Guiyang, China $\left(26.53^{\circ} \mathrm{N}, 106.71^{\circ} \mathrm{E}\right)$. Seeds of three Job's tears cultivars were surface sterilized with $0.1 \%(\mathrm{w} / \mathrm{v}) \mathrm{HgCl}_{2}$ for about $8 \mathrm{~min}$ and then rinsed five times with sterile distilled water. Next, seed soaking with PEG 6000 solutions with 0 (CK), -0.05 (T1), -0.1 (T2), -0.15 (T3), and -0.2 (T4) MPa osmotic potentials were applied for $24 \mathrm{~h}$ before germinated. Osmotic potentials were produced by PEG6000 solutions of $0,50,80,100$, and $120 \mathrm{~g} \cdot \mathrm{L}^{-1}$ according to equation supplied by Michel and Kaufmann [12]. Fifty seeds were placed in sterilized plastic trays $(24 \mathrm{~cm} \times 24 \mathrm{~cm} \times 12 \mathrm{~cm})$ covered at the bottom with three layers of filter paper that had been autoclaved. The plastic trays were supplied with $5 \mathrm{~mL}$ of tested osmotic solutions (PEG 6000 solutions, osmotic potentials of $0,-0.05,-0.1,-0.15$, and $-0.2 \mathrm{MPa})$. Germination tests were carried out in a controlled growth chamber (RXZ-1000B, Ningbo Southeast Instrument Co., Ltd, Ningbo, China) at $25{ }^{\circ} \mathrm{C} \pm 1^{\circ} \mathrm{C}$ with $12 \mathrm{~h}$ light $\left(340 \mu \mathrm{mol} \cdot \mathrm{m}^{-2} \cdot \mathrm{s}^{-1}\right)$ and $12 \mathrm{~h}$ dark photo-cycle. The relative humidity was maintained at $85 \%$ to prevent high evaporation of the medium. A further $1 \mathrm{~mL}$ of tested osmotic solutions was added daily to each plastic tray.

\subsection{Determination of Germination Parameters}

Seeds were considered germinated when the radicle was at least $1 \mathrm{~mm}$ length. The number of germinated seeds was recorded daily. The germination energy was calculated as $N_{4} / N \times 100 \%$ and the germination rate was calculated as $N_{8} / N$ $\times 100 \%$, where $N_{4}$ is the number of germinated seeds at 4 days, $\mathrm{N}_{8}$ is the number of germinated seeds at 8 days, and $N$ is the total number of tested seeds. The 
germination index was calculated as $\mathrm{nd}_{2}+0.75 \mathrm{nd}_{4}+0.50 \mathrm{nd}_{6}+0.25 \mathrm{nd}$ according to Qin et al. [13], where $\mathrm{nd}_{2}, \mathrm{nd}_{4}, \mathrm{nd}_{6}$, and $\mathrm{nd}_{8}$ are the germination rate at 2 , 4,6 , and 8 days, respectively.

\subsection{Determination of Growth Parameters}

Plants were harvested after 10 days of drought stress treatments and five plants were selected randomly from each plastic tray. The seedling length refers to the distance from the seedling base to the top of seedling. The root length refers to the distance from the taproot base to the top of taproot. The diameters of seedling and root were measured with a digital caliper having accuracy of $0.001 \mathrm{~mm}$. The fresh masses of seedling and root were the fresh weights of seedling and root, respectively. The dry masses of seedling and root were measured after drying in an oven at $80^{\circ} \mathrm{C}$ for $24 \mathrm{~h}$.

\subsection{Determination of Relative Water Content (RWC)}

Five seedlings were collected randomly from each plastic tray after 10 days of drought stress treatments and the fresh mass (FM) was determined, followed by flotation on distilled water for 12 hat room temperature. The hydrated seedling tissues were weighed to determine the turgid mass (TM). The seedling tissues were subsequently dried in an oven at $80^{\circ} \mathrm{C}$ for $24 \mathrm{~h}$ and weighed to determine the dry masse $(\mathrm{DW})$. The RWC was calculated as $[(\mathrm{FM}-\mathrm{DM}) /(\mathrm{TM}-\mathrm{DM})] \times$ $100 \%$ according to Smart and Bingham [14].

\subsection{Determination of $\mathrm{H}_{2} \mathrm{O}_{2}$, Malondialdehyde (MDA), and Proline Contents}

$\mathrm{H}_{2} \mathrm{O}_{2}$ content was assayed according to the method of Gietler et al. [15]. $0.5 \mathrm{~g}$ of seedling were collected after 10 days of drought stress treatments and homogenized with a pestle in a mortar, which contained $5 \mathrm{~mL}$ of $50 \mathrm{mM}$ phosphate buffer ( $\mathrm{pH}$ 6.5). The homogenate was centrifuged at $6000 \times \mathrm{g}$ for $25 \mathrm{~min}$. The supernatant was mixed with $0.1 \%$ (w/v) titanium chloride and $20 \%(\mathrm{v} / \mathrm{v}) \mathrm{H}_{2} \mathrm{SO}_{4}$, and then centrifuged at $6000 \times \mathrm{g}$ for $15 \mathrm{~min}$. The absorbance of the titanium peroxide complex at $410 \mathrm{~nm}$ was measured and $\mathrm{H}_{2} \mathrm{O}_{2}$ content was calculated using an extinction coefficient of $0.28 \mu \mathrm{M}^{-1} \cdot \mathrm{cm}^{-1}$.

MDA content was assayed according to the method of Akcay et al. [6]. $0.5 \mathrm{~g}$ of seedling were collected after 10 days of drought stress treatments and homogenized with a pestle in a mortar, which contained $1 \mathrm{mLof} 5 \%(\mathrm{w} / \mathrm{v})$ trichloroacetic acid. The homogenate was centrifuged at $12,000 \times \mathrm{g}$ for $15 \mathrm{~min}$ at room temperature. $0.2 \mathrm{~mL}$ of supernatant was mixed with $1 \mathrm{~mL}$ of $0.5 \%(\mathrm{w} / \mathrm{v})$ thiobarbituric acid and $20 \%(\mathrm{w} / \mathrm{v})$ trichloroacetic acid, and incubated in a water bath for 25 $\min$ at $96^{\circ} \mathrm{C}$. The reaction was stopped by placing the reaction tubes in an ice bath. Then the samples were centrifuged at 10,000 $\mathrm{g}$ for $5 \mathrm{~min}$. Absorbance of supernatant was measured at $532 \mathrm{~nm}$ and the correction for non-specific turbidity was performed by subtracting the absorbance at $600 \mathrm{~nm}$. MDA content was 
calculated using an extinction coefficient of $155 \mathrm{mM}^{-1} \cdot \mathrm{cm}^{-1}$.

Proline content was assayed by a modification method of Bates et al. [16]. 0.5 $\mathrm{g}$ of seedling were collected after 10 days of drought stress treatments and homogenized with liquid nitrogen. The seedling powders were mixed with $1 \mathrm{~mL}$ of $3 \%(\mathrm{w} / \mathrm{v})$ sulphosalicilic acid and centrifuged at $1000 \times \mathrm{g}$ for $5 \mathrm{~min}$ at $4^{\circ} \mathrm{C} .0 .1 \mathrm{~mL}$ of supernatant was mixed with $0.1 \mathrm{~mL}$ of $3 \%(\mathrm{w} / \mathrm{v})$ sulphosalicilic acid, $0.2 \mathrm{~mL}$ of $96 \%(\mathrm{v} / \mathrm{v})$ acetic acid and $0.2 \mathrm{~mL}$ acid ninhydrin, and incubated in a water bath at $96{ }^{\circ} \mathrm{C}$. After $1 \mathrm{~h}$, the mixtures were mixed with $1 \mathrm{~mL}$ toluene and centrifuged at $1000 \times \mathrm{g}$ for $5 \mathrm{~min}$ at $4^{\circ} \mathrm{C}$. Absorbance of supernatant was measured at $520 \mathrm{~nm}$ and proline content was calculated using an extinction coefficient of 0.9986 $\mathrm{mM}^{-1} \cdot \mathrm{cm}^{-1}$.

\subsection{Determination of Enzymes Activities}

Five seedlings were collected randomly from each plastic tray after 10 days of drought stress treatments and immediately frozen in liquid nitrogen for $30 \mathrm{~min}$, then kept $-60^{\circ} \mathrm{C}$ for analysis of enzymes activities.

POD activity was assayed according to the method of Wang et al. [17]. $0.5 \mathrm{~g}$ of seedling samples were homogenized with a pestle in an ice-cold mortar, which contained $5 \mathrm{~mL}$ of $50 \mathrm{mM}$ phosphate buffer ( $\mathrm{pH} \mathrm{5.5)}$ ) and $0.2 \mathrm{~g}$ PVP. The homogenate was centrifuged at $3000 \times \mathrm{g}$ for $10 \mathrm{~min}$ at $4^{\circ} \mathrm{C} .0 .1 \mathrm{~mL}$ of supernatant was mixed with $1 \mathrm{~mL}$ of $50 \mathrm{mM}$ guaiacol, $2.9 \mathrm{~mL}$ of $50 \mathrm{mM}$ phosphate buffer $(\mathrm{pH}$ $5.5)$, and $1 \mathrm{~mL}$ of $2 \%(\mathrm{v} / \mathrm{v}) \mathrm{H}_{2} \mathrm{O}_{2}$, and incubated in a water bath at $37^{\circ} \mathrm{C}$. After 5 min, the absorbance at $470 \mathrm{~nm}$ was measured by a spectrophotometer. One unit of enzyme activity (U) was defined as a change of 0.01 in absorbance per h.

CAT activity was assayed by a modification method of Gong et al. [18]. $0.5 \mathrm{~g}$ of seedling samples were homogenized with a pestle in an ice-cold mortar, which contained $1 \mathrm{~mL} 50 \mathrm{mM}$ Tris- $\mathrm{HCl}$ ( $\mathrm{pH}$ 7.8). The homogenate was centrifuged at $10,000 \times \mathrm{g}$ for $10 \mathrm{~min}$ at $4^{\circ} \mathrm{C}$. $0.2 \mathrm{~mL}$ of homogenate was mixed with $3 \mathrm{~mL}$ of reaction mixture (50 $\mathrm{mM}$ potassium phosphate buffer, $\mathrm{pH} 7.7,10 \mathrm{mM} \mathrm{H}_{2} \mathrm{O}_{2}$ ). After $30 \mathrm{~min}$, the reaction was stopped by adding $20 \%(\mathrm{v} / \mathrm{v}) \mathrm{H}_{2} \mathrm{SO}_{4}$ and the residual hydrogen peroxide was titrated against potassium permanganate. Absorbance at $240 \mathrm{~nm}$ was measured by a spectrophotometer. One unit of enzyme activity (U) was defined as a change of 0.01 in absorbance per $h$.

APX activity was assayed by a modification method of Nakano et al. [19]. 0.5 $\mathrm{g}$ of seedling samples were homogenized with a pestle in an ice-cold mortar, which contained $5 \mathrm{~mL}$ of buffer ( $50 \mathrm{mM}$ potassium phosphate buffer, $\mathrm{pH}$ 7.0, 2 $\mathrm{mM}$ ascorbate, $5 \mathrm{mM}$ EDTA, $0.2 \mathrm{~g}$ PVP). The homogenate was centrifuged at $16,000 \times \mathrm{g}$ for $20 \mathrm{~min}$ at $4^{\circ} \mathrm{C}$. $30 \mu \mathrm{L}$ of supernatant was mixed with $0.97 \mathrm{~mL}$ of 0.1 $\mathrm{mM} \mathrm{H}_{2} \mathrm{O}_{2}$ and the absorbance at $290 \mathrm{~nm}$ was measured. One unit of enzyme activity (U) was defined as a change of 0.01 in absorbance per $h$.

GR activity was assayed according to the method of Akcay et al. [6], with some modifications. $0.5 \mathrm{~g}$ of seedling samples were homogenized with a pestle in an ice-cold mortar, which contained $5 \mathrm{~mL}$ of buffer $(100 \mathrm{mM}$ potassium phos- 
phate buffer, $\mathrm{pH} 7.8,1 \%(\mathrm{w} / \mathrm{v})$ PVP, 50\% (v/v) Triton X-100, $0.1 \mathrm{mM}$ EDTA). The homogenate was centrifuged at $10,000 \times \mathrm{g}$ for $30 \mathrm{~min}$ at $4^{\circ} \mathrm{C} .0 .2 \mathrm{~mL}$ of supernatant was mixed with $3 \mathrm{~mL}$ of reaction mixture $(200 \mathrm{mM}$ potassium phosphate buffer, $\mathrm{pH} 7.5,1.5 \mathrm{mM} \mathrm{MgCl}_{2}, 0.2 \mathrm{mM}$ EDTA, $25 \mu \mathrm{M}$ NADPH, $0.25 \mathrm{mM}$ GSSH). The absorbance at $340 \mathrm{~nm}$ was measured was measured. One unit of enzyme activity (U) was defined as a change of 0.01 in absorbance per h.

\subsection{Statistical Analyses}

Analysis of variance was performed with SPSS 19.0 software (Statistical Package for Social Sciences, SPSS Institute Inc., Illinois), and data from each sampling data were analyzed separately. Means were tested by least significant difference at the $5 \%$ probability level $\left(\mathrm{LSD}_{0.05}\right)$.

\section{Results}

\subsection{Seed Germination}

Germination energy and germination rate of both cultivars were affected considerably by PEG treatments, and yy18-1 showed higher germination energy and germination rate than yy12-7 in the same PEG treatment (Table 1). It was observed that in all of cultivars there were decreases in germination energy and germination rate due to drought stress increment. Germination energy and germination rate of both cultivars significantly decreased when they were subjected to PEG6000 solution with below $-0.1 \mathrm{MPa}$ osmotic potential, but no significant changes were observed at the osmotic potential of $-0.05 \mathrm{MPa}$. Retardations of germination energy and germination rate were clearer in yy12-7 when compared to yy18-1.

Table 1. Effects of drought stress simulated by PEG on seed germination in Job's tears.

\begin{tabular}{ccccc}
\hline Cultivars & Treatments & Germination energy (\%) & Germination rate (\%) & Germination index \\
\hline & CK & $66.48 \pm 1.25 \mathrm{a}$ & $94.45 \pm 5.34 \mathrm{a}$ & $1.58 \pm 0.14 \mathrm{a}$ \\
yy18-1 & T1 & $62.06 \pm 2.32 \mathrm{ab}$ & $87.02 \pm 4.15 \mathrm{ab}$ & $1.47 \pm 0.23 \mathrm{a}$ \\
& T2 & $53.74 \pm 1.87 \mathrm{~b}$ & $75.04 \pm 2.87 \mathrm{~b}$ & $1.09 \pm 0.05 \mathrm{~b}$ \\
& T3 & $39.10 \pm 1.06 \mathrm{c}$ & $57.75 \pm 2.39 \mathrm{c}$ & $0.86 \pm 0.06 \mathrm{bc}$ \\
& T4 & $26.75 \pm 1.19 \mathrm{~d}$ & $35.47 \pm 2.01 \mathrm{~d}$ & $0.77 \pm 0.08 \mathrm{c}$ \\
& CK & $52.48 \pm 2.41 \mathrm{a}$ & $84.31 \pm 3.56 \mathrm{a}$ & $1.12 \pm 0.16 \mathrm{a}$ \\
& T1 & $42.96 \pm 2.08 \mathrm{ab}$ & $47.72 \pm 4.33 \mathrm{ab}$ & $1.01 \pm 0.08 \mathrm{a}$ \\
Ty12-7 & $24.90 \pm 0.86 \mathrm{c}$ & $33.08 \pm 0.98 \mathrm{c}$ & $0.77 \pm 0.04 \mathrm{~b}$ \\
& T2 & $10.44 \pm 1.02 \mathrm{~d}$ & $13.40 \pm 1.56 \mathrm{~d}$ & $0.57 \pm 0.01 \mathrm{c}$ \\
& & $5.74 \pm 0.54 \mathrm{~d}$ & $9.66 \pm 0.81 \mathrm{~d}$ & $0.44 \pm 0.02 \mathrm{c}$
\end{tabular}

CK, T1, T2, T3, and T4 are polyethylene glycol 6000 solutions with $0,-0.05,-0.1,-0.15$, and $-0.2 \mathrm{MPa}$ osmotic potentials, respectively. Data are presented as the mean \pm standard error of three replicates. Values followed by different letters within a column are significantly different at the $5 \%$ probability level. 
Germination index decreased with the decrease of the osmotic potential of PEG 6000 solution in both cultivars, and yy18-1 showed higher germination index than yy12-7 in the same PEG treatment (Table 1). Besides, there were significant differences between control and drought stress treatments except for the osmotic potential of $-0.05 \mathrm{MPa}$ for germination index in both cultivars. Compared with the control, the T1, T2, T3, and T4 treatments decreased the germination index by $6.77 \%, 30.66 \%, 45.67 \%$, and $51.37 \%$, respectively for yy $18-1$, and decreased that by $9.25 \%, 31.34 \%, 49.25 \%$, and $60.30 \%$, respectively for yy $12-7$.

\subsection{Root and Seedling Growth}

Root length and root diameter of yy18-1 were higher than those of yy12-7 in the same PEG treatment, which showed decrease trends with the decrease of the osmotic potential of PEG 6000 solution in both cultivars (Table 2). There were significant differences between control and drought stress treatments except for the osmotic potential of $-0.05 \mathrm{MPa}$ for root length and root diameter in both cultivars. In addition, at the same drought stress treatment, compared with the control treatment, the decreasing amplitudes of root length and root diameter of yy12-7 were higher than those of yy18-1.

Root fresh mass and root dry mass of both cultivars were affected considerably by PEG 6000 solution treatments, and yy18-1 showed higher root fresh mass and root dry mass than yy12-7 in the same PEG treatment (Table 2). It was observed that in all of cultivars there were decreases in root fresh mass and root dry mass due to drought stress increment. Root fresh mass and root dry mass of both cultivars significantly decreased when they were subjected to PEG 6000 solution with below -0.1 MPa osmotic potential, but no significant changes were

Table 2. Effects of drought stress simulated by PEG on root growth in Job's tears.

\begin{tabular}{cccccc}
\hline Cultivars & Treatments & $\begin{array}{c}\text { Root length } \\
(\mathrm{cm})\end{array}$ & $\begin{array}{c}\text { Root diameter } \\
(\mathrm{mm})\end{array}$ & $\begin{array}{c}\text { Root fresh mass } \\
(\mathrm{mg})\end{array}$ & $\begin{array}{c}\text { Root dry mass } \\
(\mathrm{mg})\end{array}$ \\
\hline & CK & $5.87 \pm 0.58 \mathrm{a}$ & $5.36 \pm 0.19 \mathrm{a}$ & $78.06 \pm 3.28 \mathrm{a}$ & $30.88 \pm 2.56 \mathrm{a}$ \\
yy18-1 & T1 & $5.44 \pm 0.17 \mathrm{ab}$ & $5.13 \pm 0.27 \mathrm{ab}$ & $72.40 \pm 4.78 \mathrm{ab}$ & $28.60 \pm 1.77 \mathrm{ab}$ \\
& T2 & $5.21 \pm 0.24 \mathrm{~b}$ & $5.06 \pm 0.35 \mathrm{bc}$ & $57.03 \pm 5.46 \mathrm{~b}$ & $25.18 \pm 0.98 \mathrm{bc}$ \\
& T3 & $4.69 \pm 0.35 \mathrm{bc}$ & $4.88 \pm 0.41 \mathrm{~cd}$ & $39.10 \pm 3.24 \mathrm{c}$ & $22.88 \pm 2.35 \mathrm{c}$ \\
& T4 & $4.00 \pm 0.31 \mathrm{c}$ & $4.38 \pm 0.58 \mathrm{~d}$ & $36.26 \pm 5.37 \mathrm{c}$ & $19.32 \pm 3.41 \mathrm{~d}$ \\
& CK & $4.40 \pm 0.42 \mathrm{a}$ & $4.68 \pm 0.62 \mathrm{a}$ & $57.63 \pm 6.54 \mathrm{a}$ & $17.72 \pm 2.87 \mathrm{a}$ \\
& T1 & $3.95 \pm 0.25 \mathrm{ab}$ & $4.10 \pm 0.33 \mathrm{ab}$ & $50.97 \pm 7.86 \mathrm{a}$ & $15.92 \pm 2.05 \mathrm{ab}$ \\
& T2 & $3.59 \pm 0.19 \mathrm{~b}$ & $3.92 \pm 0.06 \mathrm{~b}$ & $31.64 \pm 3.28 \mathrm{~b}$ & $13.82 \pm 1.25 \mathrm{~b}$ \\
& & & & & \\
& T3 & $3.21 \pm 0.08 \mathrm{c}$ & $3.56 \pm 0.18 \mathrm{c}$ & $27.99 \pm 2.59 \mathrm{bc}$ & $9.51 \pm 0.94 \mathrm{c}$ \\
& T4 & $2.91 \pm 0.16 \mathrm{c}$ & $3.34 \pm 0.26 \mathrm{c}$ & $25.54 \pm 4.24 \mathrm{c}$ & $4.45 \pm 0.86 \mathrm{~d}$ \\
\hline
\end{tabular}

CK, T1, T2, T3, and T4 are polyethylene glycol 6000 solutions with $0,-0.05,-0.1,-0.15$, and $-0.2 \mathrm{MPa}$ osmotic potentials, respectively. Data are presented as the mean \pm standard error of three replicates. Values followed by different letters within a column are significantly different at the $5 \%$ probability level. 
observed at the osmotic potential of $-0.05 \mathrm{MPa}$. Retardations of root fresh mass and root dry mass were clearer in yy12-7 when compared to yy18-1.

Seedling length and seedling diameter decreased with the decrease of the osmotic potential of PEG 6000 solution in both cultivars, and yy18-1 showed higher seedling diameter and seedling diameter than yy12-7 in the same PEG treatment (Table 3). There were significant differences between control and drought stress treatments except for the osmotic potential of $-0.05 \mathrm{MPa}$ for seedling diameter and seedling diameter in both cultivars. Besides, at the same drought stress treatment, compared with the control treatment, the decreasing amplitudes of seedling length and seedling diameter of yy12-7 were higher than those of yy18-1.

Seedling fresh mass and seedling dry mass of yy18-1 was higher than those of yy12-7 in the same PEG treatment, which showed decrease trends with the decrease of the osmotic potential of PEG 6000 solution in both cultivars (Table 3). There were significant differences between control and drought stress treatments except for the osmotic potential of $-0.05 \mathrm{MPa}$ for seedling fresh mass and seedling dry mass in both cultivars. In addition, at the same drought stress treatment, compared with the control treatment, the decreasing amplitudes of seedling fresh mass and seedling dry mass of yy12-7 were higher than those of yy18-1.

\subsection{RWC and Contents of $\mathrm{H}_{2} \mathrm{O}_{2}, \mathrm{MDA}$, and Proline}

Under no PEG treatment, both cultivars showed almost identical RWC (91.87\% in yy18-1 and $90.32 \%$ in yy12-7). However, drought stress caused the deleterious effects in RWC of both yy18-1 and yy12-7 (Table 4). RWC of both cultivars significantly decreased when it was subjected to PEG 6000 solution with below -0.1

Table 3. Effects of drought stress simulated by PEG on seedling growth in Job's tears.

\begin{tabular}{|c|c|c|c|c|c|}
\hline Cultivars & Treatments & $\begin{array}{l}\text { Seedling length } \\
(\mathrm{cm})\end{array}$ & $\begin{array}{l}\text { Seedling diameter } \\
(\mathrm{mm})\end{array}$ & $\begin{array}{l}\text { Seedling fresh mass } \\
(\mathrm{mg})\end{array}$ & $\begin{array}{c}\text { Seedling dry mass } \\
(\mathrm{mg})\end{array}$ \\
\hline \multirow{5}{*}{ yy18-1 } & $\mathrm{CK}$ & $11.38 \pm 1.17 \mathrm{a}$ & $6.82 \pm 0.74 \mathrm{a}$ & $127.58 \pm 9.56 \mathrm{a}$ & $47.40 \pm 5.97 \mathrm{a}$ \\
\hline & $\mathrm{T} 1$ & $11.14 \pm 2.35 \mathrm{a}$ & $6.66 \pm 0.26 \mathrm{ab}$ & $119.97 \pm 8.34 \mathrm{ab}$ & $44.51 \pm 3.37 \mathrm{a}$ \\
\hline & $\mathrm{T} 2$ & $10.34 \pm 1.87 \mathrm{~b}$ & $6.31 \pm 0.17 \mathrm{~b}$ & $110.60 \pm 5.65 b c$ & $37.39 \pm 2.98 b$ \\
\hline & T3 & $9.77 \pm 0.24 \mathrm{c}$ & $5.78 \pm 0.23 c$ & $103.69 \pm 7.43 \mathrm{~cd}$ & $29.60 \pm 3.05 c$ \\
\hline & $\mathrm{T} 4$ & $8.99 \pm 0.98 \mathrm{~d}$ & $5.68 \pm 0.31 \mathrm{c}$ & $93.59 \pm 3.58 \mathrm{~d}$ & $25.82 \pm 4.04 \mathrm{c}$ \\
\hline \multirow{5}{*}{ yy12-7 } & CK & $9.01 \pm 0.56 \mathrm{a}$ & $4.38 \pm 0.08 \mathrm{a}$ & $85.18 \pm 4.11 \mathrm{a}$ & $37.17 \pm 2.18 \mathrm{a}$ \\
\hline & $\mathrm{T} 1$ & $8.47 \pm 0.34 \mathrm{ab}$ & $4.14 \pm 0.15 \mathrm{ab}$ & $77.27 \pm 3.97 \mathrm{ab}$ & $31.60 \pm 1.75 \mathrm{ab}$ \\
\hline & $\mathrm{T} 2$ & $7.95 \pm 0.81 \mathrm{~b}$ & $4.04 \pm 0.86 \mathrm{bc}$ & $66.32 \pm 4.08 b$ & $26.93 \pm 2.39 \mathrm{bc}$ \\
\hline & T3 & $7.44 \pm 0.48 b$ & $3.68 \pm 0.93 c$ & $61.68 \pm 5.02 c$ & $22.48 \pm 2.45 \mathrm{~cd}$ \\
\hline & $\mathrm{T} 4$ & $6.32 \pm 0.57 c$ & $3.52 \pm 0.55 c$ & $57.42 \pm 4.39 \mathrm{~d}$ & $19.14 \pm 1.86 \mathrm{~d}$ \\
\hline
\end{tabular}

CK, T1, T2, T3, and T4 are polyethylene glycol 6000 solutions with $0,-0.05,-0.1,-0.15$, and $-0.2 \mathrm{MPa}$ osmotic potentials, respectively. Data are presented as the mean \pm standard error of three replicates. Values followed by different letters within a column are significantly different at the $5 \%$ probability level. 
Table 4. Effects of drought stress simulated by PEG on RWC and contents of $\mathrm{H}_{2} \mathrm{O}_{2}, \mathrm{MDA}$, and proline of seedling in Job's tears.

\begin{tabular}{cccccc}
\hline Cultivars & Treatments & RWC (\%) & $\begin{array}{c}\mathrm{H}_{2} \mathrm{O}_{2} \text { content } \\
\left(\mathrm{nmol} \cdot \mathrm{g}^{-1} \mathrm{FM}\right)\end{array}$ & $\begin{array}{c}\text { MDA content } \\
\left(\mathrm{mmol} \cdot \mathrm{g}^{-1} \mathrm{FM}\right)\end{array}$ & $\begin{array}{c}\text { Proline content } \\
\left(\mathrm{mg} \cdot \mathrm{g}^{-1} \mathrm{FM}\right)\end{array}$ \\
\hline & $\mathrm{CK}$ & $91.87 \pm 5.35 \mathrm{a}$ & $6.56 \pm 0.83 \mathrm{c}$ & $10.58 \pm 2.31 \mathrm{c}$ & $3.73 \pm 0.18 \mathrm{c}$ \\
yy18-1 & $\mathrm{T} 1$ & $87.65 \pm 4.24 \mathrm{a}$ & $6.93 \pm 0.35 \mathrm{c}$ & $14.55 \pm 1.87 \mathrm{bc}$ & $3.95 \pm 0.21 \mathrm{bc}$ \\
& T2 & $73.24 \pm 6.38 \mathrm{~b}$ & $7.87 \pm 0.42 \mathrm{~b}$ & $18.35 \pm 2.24 \mathrm{~b}$ & $4.35 \pm 0.35 \mathrm{~b}$ \\
& T3 & $67.36 \pm 3.21 \mathrm{c}$ & $8.33 \pm 0.17 \mathrm{ab}$ & $20.34 \pm 3.05 \mathrm{ab}$ & $4.76 \pm 0.47 \mathrm{ab}$ \\
& T4 & $62.41 \pm 1.57 \mathrm{c}$ & $9.24 \pm 0.54 \mathrm{a}$ & $23.59 \pm 2.91 \mathrm{a}$ & $5.38 \pm 0.29 \mathrm{a}$ \\
& $\mathrm{CK}$ & $90.32 \pm 8.76 \mathrm{a}$ & $6.63 \pm 0.38 \mathrm{~d}$ & $13.47 \pm 2.88 \mathrm{~d}$ & $2.86 \pm 0.33 \mathrm{c}$ \\
& $\mathrm{T} 1$ & $81.35 \pm 5.33 \mathrm{ab}$ & $8.03 \pm 0.31 \mathrm{c}$ & $18.77 \pm 3.02 \mathrm{~d}$ & $3.01 \pm 0.41 \mathrm{c}$ \\
& $\mathrm{T} 2$ & $69.54 \pm 2.19 \mathrm{~b}$ & $9.42 \pm 0.27 \mathrm{~b}$ & $24.36 \pm 1.59 \mathrm{c}$ & $3.32 \pm 0.19 \mathrm{~b}$ \\
& $\mathrm{~T} 3$ & $60.13 \pm 3.58 \mathrm{c}$ & $10.15 \pm 0.46 \mathrm{~b}$ & $31.58 \pm 2.03 \mathrm{~b}$ & $3.54 \pm 0.27 \mathrm{~b}$ \\
& $\mathrm{~T} 4$ & $54.26 \pm 2.71 \mathrm{~d}$ & $12.47 \pm 0.57 \mathrm{a}$ & $39.74 \pm 3.47 \mathrm{a}$ & $4.05 \pm 0.49 \mathrm{a}$ \\
\hline
\end{tabular}

CK, T1, T2, T3, and T4 are polyethylene glycol 6000 solutions with $0,-0.05,-0.1,-0.15$, and $-0.2 \mathrm{MPa}$ osmotic potentials, respectively. RWC, $\mathrm{H}_{2} \mathrm{O}_{2}$, and MAD stands for relative water content, hydrogen peroxide, and malondialdehyde, respectively. Data are presented as the mean \pm standard error of three replicates. Values followed by different letters within a column are significantly different at the $5 \%$ probability level.

MPa osmotic potential, but no significant change was observed at the osmotic potential of $-0.05 \mathrm{MPa}$. Besides, at the same drought stress treatment, compared with the control treatment, the decreasing amplitude of RWC of yy18-1 was lower than that of yy12-7.

Similarly, $\mathrm{H}_{2} \mathrm{O}_{2}$ content of both cultivars in the no PEG treatment was almost identical and independent of their drought resistance (Table 4). It was observed that in all of cultivars there was an increase in $\mathrm{H}_{2} \mathrm{O}_{2}$ content due to drought stress increment. There were significant differences between control and drought stress treatments except for the osmotic potential of $-0.05 \mathrm{MPa}$ for $\mathrm{H}_{2} \mathrm{O}_{2}$ content in both cultivars. Compared with the control, the T1, T2, T3, and T4 treatments increased the $\mathrm{H}_{2} \mathrm{O}_{2}$ content by $5.64 \%, 19.97 \%, 26.98 \%$, and $40.85 \%$, respectively for yy $18-1$, and increased that by $21.12 \%, 42.08 \%, 53.09 \%$, and $88.08 \%$, respectively for yy12-7.

MDA content was affected considerably by PEG 6000 solution treatments, and yy18-1 showed lower MDA content than yy12-7 in the same PEG treatment (Table 4). It was observed that in all of cultivars there was an increase in MDA content due to drought stress increment. MDA content of both cultivars significantly increased when it was subjected to PEG 6000 solution with below -0.1 MPa osmotic potential, but no significant change was observed at the osmotic potential of $-0.05 \mathrm{MPa}$. Compared with the control, the T1, T2, T3, and T4 treatments increased the MDA content by $37.52 \%, 73.44 \%, 92.25 \%$, and $122.97 \%$, respectively for yy $18-1$, and increased that by $39.35 \%, 80.85 \%$, $134.45 \%$, and $195.03 \%$, respectively for yy12-7.

Proline content of yy18-1 was higher than that of yy12-7 in the same PEG 
treatment, which showed an increase trend with the decrease of the osmotic potential of PEG 6000 solution in both cultivars (Table 4). There were significant differences between control and drought stress treatments except for the osmotic potential of $-0.05 \mathrm{MPa}$ for proline content in both cultivars. In addition, the increasing amplitude of proline content was clearer in yy18-1 when compared to yy12-7.

\subsection{Enzymes Activities}

POD activity was affected considerably by PEG 6000 solution treatments, and yy18-1 showed higher POD activity than yy12-7 in the same PEG treatment (Table 5). POD activity increased and then decreased with the decrease of osmotic potential of PEG 6000 solution in both cultivars and the maximum value appeared in the $-0.1 \mathrm{MPa}$ osmotic potential treatment. Compared with the control, the $\mathrm{T} 1$ and $\mathrm{T} 2$ treatments increased the POD activity by $3.55 \%$ and $12.48 \%$ (mean of both cultivars), but the T3 and T4 treatments decreased that by $4.87 \%$ and $19.13 \%$ (mean of both cultivars), respectively.

CAT activity of yy18-1 was higher than that of yy12-7 in the same PEG treatment, which exhibited single peak curves with a peak at the $-0.1 \mathrm{MPa}$ osmotic potential treatment (Table 5). Compared with the control, the T1 and T2 treatments increased the CAT activity by $1.17 \%$ and $5.72 \%$ (mean of both cultivars), but the T3 and T4 treatments decreased that by $2.69 \%$ and $10.61 \%$ (mean of both cultivars), respectively.

APX activity was affected considerably by PEG 6000 solution treatments, and yy18-1 showed higher APX activity than yy12-7 in the same PEG treatment

Table 5. Effects of drought stress simulated by PEG on activities of POD, CAT, APX, and GR of seedling in Job's tears.

\begin{tabular}{|c|c|c|c|c|c|}
\hline Cultivars & Treatments & $\begin{array}{l}\text { POD activity } \\
\left(\mathrm{U} \cdot \mathrm{mg}^{-1} \mathrm{FM}\right)\end{array}$ & $\begin{array}{l}\text { CAT activity } \\
\left(\mathrm{U} \cdot \mathrm{mg}^{-1} \mathrm{FM}\right)\end{array}$ & $\begin{array}{l}\text { APX activity } \\
\left(\mathrm{U} \cdot \mathrm{mg}^{-1} \mathrm{FM}\right)\end{array}$ & $\begin{array}{c}\text { GR activity } \\
\left(\mathrm{U} \cdot \mathrm{mg}^{-1} \mathrm{FM}\right)\end{array}$ \\
\hline \multirow{5}{*}{ yy18-1 } & $\mathrm{CK}$ & $23.47 \pm 1.87 \mathrm{~b}$ & $7.49 \pm 0.39 \mathrm{~b}$ & $38.76 \pm 5.46 b$ & $17.65 \pm 1.93 b$ \\
\hline & $\mathrm{T} 1$ & $24.36 \pm 0.96 \mathrm{ab}$ & $7.58 \pm 0.92 \mathrm{ab}$ & $39.42 \pm 3.27 b$ & $18.03 \pm 1.46 \mathrm{ab}$ \\
\hline & $\mathrm{T} 2$ & $26.94 \pm 2.34 \mathrm{a}$ & $7.64 \pm 0.84 \mathrm{a}$ & $41.35 \pm 2.51 \mathrm{a}$ & $20.15 \pm 2.06 a$ \\
\hline & $\mathrm{T} 3$ & $23.02 \pm 2.91 \mathrm{~b}$ & $7.24 \pm 0.73 b c$ & $37.18 \pm 1.19 \mathrm{bc}$ & $17.02 \pm 1.97 \mathrm{~b}$ \\
\hline & $\mathrm{T} 4$ & $20.18 \pm 1.09 c$ & $6.97 \pm 0.15 c$ & $36.87 \pm 2.92 c$ & $16.39 \pm 2.35 c$ \\
\hline \multirow{5}{*}{ уу12-7 } & $\mathrm{CK}$ & $20.45 \pm 3.36 \mathrm{~b}$ & $7.03 \pm 0.44 b$ & $32.41 \pm 3.05 b$ & $15.42 \pm 3.16 b$ \\
\hline & $\mathrm{T} 1$ & $21.12 \pm 2.54 \mathrm{a}$ & $7.11 \pm 0.19 \mathrm{ab}$ & $32.85 \pm 4.13 \mathrm{~b}$ & $15.61 \pm 0.99 \mathrm{ab}$ \\
\hline & $\mathrm{T} 2$ & $22.46 \pm 1.81 \mathrm{a}$ & $7.27 \pm 0.26 \mathrm{a}$ & $34.38 \pm 2.77 \mathrm{a}$ & $16.92 \pm 1.58 \mathrm{a}$ \\
\hline & $\mathrm{T} 3$ & $18.76 \pm 2.05 \mathrm{~b}$ & $6.54 \pm 0.31 c$ & $30.17 \pm 1.86 \mathrm{c}$ & $13.29 \pm 2.36 c$ \\
\hline & $\mathrm{T} 4$ & $15.34 \pm 3.11 \mathrm{c}$ & $6.01 \pm 0.87 c$ & $27.65 \pm 1.09 \mathrm{~d}$ & $12.18 \pm 1.05 c$ \\
\hline
\end{tabular}

CK, T1, T2, T3, and T4 are polyethylene glycol 6000 solutions with $0,-0.05,-0.1,-0.15$, and $-0.2 \mathrm{MPa}$ osmotic potentials, respectively. POD, CAT, APX, and GR stands for peroxidase, catalase, ascorbate peroxidase, and glutathione reductase, respectively. Data are presented as the mean \pm standard error of three replicates. Values followed by different letters within a column are significantly different at the $5 \%$ probability level. 
(Table 5). It was observed that in all of cultivars there was an increase and then decrease in APX activity due to drought stress increment and the maximum value appeared in the $-0.1 \mathrm{MPa}$ osmotic potential treatment. Compared with the control, the T1 and T2 treatments increased the APX activity by $1.55 \%$ and $6.41 \%$ (mean of both cultivars), but the T3 and T4 treatments decreased that by $5.37 \%$ and $9.34 \%$ (mean of both cultivars), respectively.

GR activity of yy18-1 was higher than that of yy12-7 in the same PEG treatment, which showed an increase and then decrease trend with the decrease of the osmotic potential of PEG 6000 solution in both cultivars and the maximum value appeared in the $-0.1 \mathrm{MPa}$ osmotic potential treatment (Table 5). Compared with the control, the T1 and T2 treatments increased the GR activity by $1.72 \%$ and $12.10 \%$ (mean of both cultivars), but the T3 and T4 treatments decreased that by $8.35 \%$ and $13.61 \%$ (mean of both cultivars), respectively.

\section{Discussion}

In general, germination is often considered to contain the process from sowing until the full emergence of the cotyledon leaves [20]. There are, in fact, three different phases during this germination period, i.e., seed germination, root growth, and seedling growth. If all three of these phases are better understood and dealt with together, it would be helpful in the evaluation of the drought resistance in crops [21]. Parameters of seed germination (germination energy, germination rate, and germination index), root growth (root length, root diameter, root fresh mass, and root dry mass), and seedling growth (seedling length, seedling diameter, seedling fresh mass, and seedling dry mass) are important indicators to evaluate the drought resistance at germination stage in the crops production [9]. In the present study, at the same PEG treatment, means of all tested indices of yy18-1 were higher than those of yy12-7. Thus, yy18-1 is a cultivar with high resistance to drought stress and yy12-7 is a cultivar with susceptible to drought stress, which are consistent with their field performances. Generally, seed germination is determined by the seed quality and environmental conditions [4]. In our study, at the control treatment (without considering drought stress), the significantly higher germination energy, germination rate, and germination index of yy18-1 compared with yy12-7 $(P<0.05)$ indicated that the seed quality (at the same environmental conditions) of yy18-1 was better than that of yy12-7. Besides, both root growth and seedling growth of yy18-1 were also significantly higher than those of yy12-7 $(P<0.05)$ also confirm the above conclusion. This may be due to the different 1000-grain weights (113.64 $\mathrm{g}$ and $95.47 \mathrm{~g}$ for yy18-1 and yy12-7, respectively), which could provide different nutrient supplies for seed germination, root growth, and seedling growth.

Drought stress is the main constraint for crop production in the world and a better understanding of germination responses to drought stress may be helpful in crop improvement program directed toward the generation of drought resistance cultivars [10]. Drought stress simulated by PEG at the germination stage 
affected the seed germination, root growth, and seedling growth in various crops [11]. In the present study, the germination energy, germination rate, and germination index decreased with the decrease of the osmotic potential of PEG 6000 solution in both cultivars, which are in agreement with those reported by Gholami et al. [22]. However, Almansouri et al. [23] concluded that moderate drought stress only delayed germination while high drought stress reduced the final germination rate. Further studies are needed to determine the cause of these differences. The root growth and seedling growth provide some important clues to the responses of crops to drought stress [4]. In this study, a special reduction in the root length, root diameter, root fresh mass, root dry mass, seedling length, seedling diameter, seedling fresh mass, and seedling dry mass of both cultivars was observed because of drought stress simulated by PEG. The results are in agreement with the earlier study who reported the drought stress affects the root growth and seedling growth negatively [24]. In addition, at the same drought stress treatment, compared with the control treatment, the decreasing amplitudes of all tested indices of yy12-7 were higher than those of yy18-1. Therefore, Job's tears cultivars showing high resistance to drought stress, had a higher defense capability than other cultivars.

Germination is one of the most important stages in the crop life cycle and resistance against drought during the germination makes a crop stable [5]. The PEG is an inert, water-binding polymer, with a nonionic and virtually impermeable long chain, which accurately mimics drought stress under drought conditions. If the optimal osmotic potential of drought stress simulated by PEG is better determined, it would be helpful in the drought resistance identification, drought resistance indices screening, and drought resistance cultivar breeding in crops [10]. In the present study, compared with the control treatments, parameters of seed germination, root growth, and seedling growth of both cultivars did not show significant differences when the osmotic potential of PEG solution was more than $-0.1 \mathrm{MPa}$. In addition, excessively inhibition of above indices was appeared in both cultivars when the osmotic potential of PEG solution was less than $-0.1 \mathrm{MPa}$. Based on the present results, it is suggested that $-0.1 \mathrm{MPa}$ was the optimal osmotic potential of PEG 6000 solution simulated drought stress at germination stage for Job's tears.

RWC expresses the capacity of conserving cellular hydration under physiological water starvation through osmotic adjustment. $\mathrm{H}_{2} \mathrm{O}_{2}$ is a strong oxidant that can initiate localised oxidative damage leading to disruption of metabolic function and losses of cellular integrity at sites where it accumulates. MDA, the product of membrane lipid peroxidation, is one of the major indices estimating damaging extent of membrane system by drought stress [10]. In this study, RWC, $\mathrm{H}_{2} \mathrm{O}_{2}$ content, and MDA content of seedling were significantly affected by PEG treatment. It was observed that in all of cultivars there were increases in $\mathrm{H}_{2} \mathrm{O}_{2}$ and MDA contents and a decrease in RWC due to drought stress increment, which are in agreement with those reported by $\mathrm{Du}$ et al. [25]. However, 
Akcay et al. [6] concluded that the $\mathrm{H}_{2} \mathrm{O}_{2}$ content increased and then decreased with the decrease of osmotic potential of PEG 6000 solution. Further studies are needed to determine the cause of these differences. Furthermore, our results indicated that yy18-1 showed higher RWC and lower MDA and $\mathrm{H}_{2} \mathrm{O}_{2}$ contents than yy12-7 in the same PEG treatment. Besides, at the same drought stress treatment, compared with the control treatment, the decreasing amplitude of RWC and increasing amplitudes of MDA and $\mathrm{H}_{2} \mathrm{O}_{2}$ contents of yy18-1 were lower than those of yy12-7. These results also suggested that Job's tears cultivars showing high resistance to drought stress, had a higher defense capability than other cultivars.

Proline, which is an osmoprotectant, is not only play adaptive role in mediating osmotic adjustment and protecting subcellular structures in stressed plants, but also help plants to perform better in terms of growth, photosynthesis and assimilate partitioning to grain filling [26]. In the present study, proline content was increased under drought stress simulated by PEG 6000 solution in Job's tears cultivars, and yy18-1 showed higher proline content than yy12-7 in the same PEG treatment. These results are in agreement with those reported by Alexieva et al. [27]. Therefore, proline was an essential part of the protection mechanism against drought stress in Job's tears.

Antioxidant enzymes activities constitute the major part of the plant antioxidant defense system. POD is located in cytosol, vacuole as well as in extracellular space scavenge $\mathrm{H}_{2} \mathrm{O}_{2}$ by oxidation of various substrates. CAT eliminates $\mathrm{H}_{2} \mathrm{O}_{2}$ by breaking it down to $\mathrm{H}_{2} \mathrm{O}$ and $\mathrm{O}_{2}$, which does not require any reducing equivalents [6]. A PX is located in cytosol and various organelles convert $\mathrm{H}_{2} \mathrm{O}_{2}$ to $\mathrm{H}_{2} \mathrm{O}$ using ascorbate as an electron donor [28]. GR has a central role in maintaining the reduced glutathione pool during stress [29]. In this study, activities of POD, CAT, APX, and GR increased and then decreased with the decrease of osmotic potential of PEG 6000 solution in both cultivars, and yy18-1 showed higher enzymes activities than yy12-7 in the same PEG treatment. This might be due to a toxic effect of PEG 6000 solution on seeds at higher concentration. Therefore, increases in the activities of POD, CAT, APX, and GR might have provided protection during drought conditions. However, compared with the control treatment, POD activity showed higher increasing amplitude than activities of CAT, APX, and GR during mild drought conditions (above -0.1 MPa osmotic potential) and CAT activity showed lower decreasing amplitude than activities of POD, APX, and GR during heavy drought conditions (below -0.1 MPa osmotic potential).These results indicated that POD and CAT were important mechanisms for the maintenance of drought resistance in Job's tears seedling.

\section{Conclusion}

Drought stress had significant effect on seed germination, root and seedling growth, and seedling antioxidant characteristics in Job's tears. The germination energy, germination rate, germination index, root and seedling lengths, root and 
seedling diameters, root and seedling fresh masses, root and seedling dry masses, and seedling RWC decreased with the decrease of the osmotic potential of PEG 6000 solution. The contents of $\mathrm{H}_{2} \mathrm{O}_{2}, \mathrm{MDA}$, and proline in seedling increased with the decrease of the osmotic potential of PEG 6000 solution. The activities of POD, CAT, APX, and GR in seedling increased and then decreased with the decrease of osmotic potential of PEG 6000 solution. $-0.1 \mathrm{MPa}$ was the optimal osmotic potential of PEG 6000 solution simulated drought stress at germination stage for Job's tears. The proline content and activities of POD and CAT were important mechanisms for the maintenance of drought resistance in Job's tears seedling.

\section{Acknowledgements}

This work was supported by the Guizhou Science and Technology Support Project (QKHZC20182293), the Guizhou Province Agricultural Research Project (QKHNZ20134025), and the Special Funds for Agriculture Animal and Plant Breeding in Guizhou Province (QNYZZ2012023).

\section{Conflicts of Interest}

The authors declare no conflicts of interest regarding the publication of this paper.

\section{References}

[1] Apirattananusorn, S., Tongta, S., Cui, S.W. and Wang, Q. (2008) Chemical Molecular, and Structural Characterization of Alkali Extractable Nonstarch Polysaccharides from Job's Tears. Journal of Agricultural and Food Chemistry, 56, 8549-8557. https://doi.org/10.1021/jf801231y

[2] Manosroi, J., Khositsuntiwong, N. and Manosroi, A. (2014) Biological Activities of Functooligosaccharide (FOS)-Containing Coix lacryma-jobi Linn. Extract. Journal of Food Science and Technology, 51, 341-346. https://doi.org/10.1007/s13197-011-0498-6

[3] Bao, Y., Yuan, Y.Z., Xia, L., Jiang, H., Wu, W.R. and Zhang, X.J. (2005) Neural Lipid Isolated from Endosperm of Job's Tears Inhibits the Growth of Pancreatic Cancer Cells via Apoptosis, $\mathrm{G}_{2} / \mathrm{M}$ Arrest, and Regulation of Gene Expression. Journal of Gastroenterology and Hepatology, 20, 1046-1053. https://doi.org/10.1111/j.1440-1746.2005.03864.x

[4] Khodarahmpour, Z. (2011) Effect of Drought Stress Induced by Polyethylene Glycol (PEG) on Germination Indices in Corn (Zea mays L.) Hybrids. African Journal of Biotechnology, 10, 18222-18227. https://doi.org/10.5897/AJB11.2639

[5] Shitole, S.M. and Dhumal, K.N. (2012) Effect of Water Stress by Polyethylene Glycol 6000 and Sodium Chloride on Seed Germination and Seedling Growth of Cassia angustifolia. International Journal of Pharmaceutical Sciences and Research, 3, 528-531.

[6] Akcay, U.C., Ercan, O., Kavas, M., Yildiz, L., Yilmaz, C., Oktem, H.A. and Yucel, M. (2010) Drought-Induced Oxidative Damage and Antioxidant Responses in Peanut (Arachis hypogaea L.) Seedlings. Plant Growth Regulation, 61, 21-28.

https://doi.org/10.1007/s10725-010-9445-1 
[7] Farooq, M., Wahid, A., Kobayashi, N., Fujita, D. and Basra, S.M.A. (2009) Plant Drought Stress: Effects, Mechanisms and Management. Agronomy for Sustainable Development, 29, 185-212. https://doi.org/10.1051/agro:2008021

[8] Gong, H., Zhu, X., Chen, K., Wang, S. and Zhang, C. (2005) Silicon Alleviates Oxidative Damage of Wheat Plants in Pots under Drought. Plant Science, 169, 313-321. https://doi.org/10.1016/j.plantsci.2005.02.023

[9] Almaghrabi, O.A. (2012) Impact of Drought Stress on Germination and Seedling Growth Parameters of Some Wheat Cultivars. Life Science Journal, 9, 590-598.

[10] Basu, S., Roychoudhury, A., Saha, P.P. and Sengupta, D.N. (2010) Comparative Analysis of Some Biochemical Responses of Three Indica Rice Varieties during Polyethylene Glycol-Mediated Water Stress Exhibits Distinct Varietal Differences. Acta Physiologiae Plantarum, 32, 551-563. https://doi.org/10.1007/s11738-009-0432-y

[11] Pei, Z.F., Ming, D.F., Liu, D., Wan, G.L., Geng, X.X., Gong, H.J. and Zhou, W.J. (2010) Silicon Improves the Tolerance to Water-Deficit Stress Induced by Polyethylene Glycol in Wheat (Triticum aestivum L.) Seedlings. Journal of Plant Growth Regulation, 29, 106-115. https://doi.org/10.1007/s00344-009-9120-9

[12] Michel, B.E. and Kaufmann, M.R. (1973) The Osmotic Potential of Polyethylene glycol 6000. Plant Physiology, 51, 914-916. https://doi.org/10.1104/pp.51.5.914

[13] Qin, L., Yang, Y.B., Guan, Y.A., Zhang, H.W., Wang, H.L., Liu, B. and Chen, E.Y. (2013) Identification of Drought Tolerance at Germination Period of Foxtail Millet Cultivars Developed from Different Ecological Regions. Journal of Plant Genetic Resources, 14, 146-151.

[14] Smart, R.E. and Bingham, G.E. (1974) Rapid Estimates of Relative Water Content. Plant Physiology, 53, 258-260. https://doi.org/10.1104/pp.53.2.258

[15] Gietler, M., Nykiel, M. and Zagdańska, B.M. (2016) Changes in the Reduction State of Ascorbate and Glutathione, Protein Oxidation and Hydrolysis Leading to the Development of Dehydration Intolerance in Triticum aestivum L. Seedlings. Plant Growth Regulation, 79, 287-297. https://doi.org/10.1007/s10725-015-0133-Z

[16] Bates, L.S., Waldren, R.P. and Teare, I.D. (1973) Rapid Determination of Free Proline for Water-Stress Studies. Plant and Soil, 39, 205-207. https://doi.org/10.1007/BF00018060

[17] Wang, C., Hu, D., Liu, X.B., She, H.Z., Ruan, R.W., Yang, H., Yi, Z.L. and Wu, D.Q. (2015) Effects of Uniconazole on the Lignin Metabolism and Lodging Resistance of Culm in Common Buckwheat (Fagopyrum esculentum M.). Field Crops Research, 180, 46-53. https://doi.org/10.1016/j.fcr.2015.05.009

[18] Vardhini, B.V. and Rao, S.S.R. (2003) Amelioration of Osmotic Stress by Brassinosteroids on Seed Germination and Seedling Growth of Three Varieties of Sorghum. Plant Growth Regulation, 41, 25-31. https://doi.org/10.1023/A:1027303518467

[19] Nakano, Y. and Asada, K. (1981) Hydrogen Peroxide Is Scavenged by Ascorbate-Specific Peroxidase in Spinach Chloroplasts. Plant and Cell Physiology, 22, 867-880.

[20] El-Kassaby, Y.A. and Edwards, D.G.W. (2001) Germination Ecology in Mountain Hemlock (Tsuga mertensiana (Bong.) Carr.). Forest Ecology and Management, 144, 183-188. https://doi.org/10.1016/S0378-1127(00)00370-4

[21] Parvez, S.S., Parvez, M.M., Fujii, Y. and Gemma, H. (2003) Allelopathic Competence of Tamarindus indica L. Root Involved in Plant Growth Regulation. Plant Growth Regulation, 41, 139-148. https://doi.org/10.1023/A:1027387126878

[22] Gholami, M., Rahemi, M. and Kholdebarin, B. (2010) Effect of Drought Stress In- 
duced by Polyethylene Glycol on Seed Germination of Four Wild Almond Species. Australian Journal of Basic and Applied Sciences, 4, 785-791.

[23] Almansouri, M., Kinet, J.M. and Lutts, S. (2001) Effect of Salt and Osmotic Stresses on Germination in Durum Wheat (Triticum durum Desf.). Plant and Soil, 231, 243-254. https://doi.org/10.1023/A:1010378409663

[24] Khayatnezhad, M., Gholamin, R., Jamaati-e-Somarin, S. and Zabihi-e-Mahmoodabad, R. (2010) Effects of Peg Stress on Corn Cultivars (Zea mays L.) at Germination Stage. World Applied Sciences Journal, 11, 504-506.

[25] Du, C.Y., Duan, Z.Y., Pan, Y.H., Lei, B.K., Hu, W.L., Fu, B., Chen, A.Q., Chen, S.H., Yang, Y.Q. and Jin, G.M. (2015) Effect of Drought Stress on Growth and Activities of Antioxidant Enzymes of Maize Seedling. Agricultural Research in the Arid Areas, 33, 124-129.

[26] Ashraf, M. and Foolad, M.R. (2007) Roles of Glycinebetaine and Proline in Improving Plant Abiotic Stress Resistance. Environmental and Experimental Botany, 59, 206-216. https://doi.org/10.1016/j.envexpbot.2005.12.006

[27] Alexieva, V., Sergiev, I., Mapelli, S. and Karanov, E. (2001) The Effect of Drought and Ultraviolet Radiation on Growth and Stress Markers in Pea and Wheat. Plant Cell and Environment, 24, 1337-1344 https://doi.org/10.1046/j.1365-3040.2001.00778.x

[28] Madhusudhan, R., Ishikawa, T., Sawa, Y., Shiqeoka, S. and Shibata, H. (2003) Characterization of an Ascorbate Peroxidase in Plastids of Tobacco BY-2 Cells. Physiologia Plantarum, 117, 550-557. https://doi.org/10.1034/j.1399-3054.2003.00066.x

[29] Pastori, G., Foyer, C.H. and Mullineaux, P. (2000) Low Temperature-Induced Changes in the Distribution of $\mathrm{H}_{2} \mathrm{O}_{2}$ and Antioxidants between the Bundle Sheath and Mesophyll Cells of Maize Leaves. Journal of Experimental Botany, 51, 107-113. https://doi.org/10.1093/jexbot/51.342.107

\section{Abbreviations}

APX: Ascorbate Peroxidase; CAT: Catalase; GR: Glutathione Reductase; $\mathrm{H}_{2} \mathrm{O}_{2}$ : Hydrogen Peroxide; MDA: Malondialdehyde; PEG: Polyethylene Glycol; POD: Peroxidase; RWC: Relative Water Content. 